\title{
Presentation of the post-socialist city dossier
}

Ksenija Martinovic, Guest Editor*

DOI: https://doi.org/10.47785/urbana.12.2021

The fall of the Berlin Wall in 1989 symbolically marked the collapse of the socialist system in Central and Eastern Europe. The defeat brought political, economic, social, and cultural changes to the then socialist countries, and the era of post-socialism began. The term postsocialist city was introduced to examine the long-term effects that the centrally planned system left on cities. Over the three decades, it continued to be topical among urban researchers. While some postsocialist cities were rapidly shaped by the new ideological, socio-political, economic, and cultural circumstances, others remained on the edge of this urban realm transition focus. This issue of Urbana examines the current postsocialist city development projects, policies, dynamics between the local actors and urban movements, residents' perspectives, and it focuses on different postsocialist cities.

In the opening article, Brsakoska writes about Skopje, the capital of North Macedonia, and its transformation through the "Skopje 2014" project. The author discusses the change of the urban morphology and the project's planning process, which entirely changed the urban realm of socialist Skopje from the Yugoslavia period. Kenzo Tange's idea was abandoned to recast a (North) Macedonian national identity, even though Tange's modernist concept represented the social and cultural identity of the city. In architectural terms, the "Skopje 2014" project brought "baroquesation" to the city. The article explores the architectural heritage, transformation of public space, and relationship with the community. The author shows that the urban process behind the project excluded the public and experts' opinions. Though the project has been only recently finalized, the author suggests that Skopje should revitalize its urban realm by including the community which showed resistance to the "Skopje 2014" project and finally to the government.

The second article focuses on another ex-Yugoslav country, Bosnia and Herzegovina, and its capital Sarajevo. Belasri investigates the trajectory of the shopping mall BBI Center in Sarajevo, in the past known as Sarajka, its privatization, and transformation of the attached public square - the October Square (org. Trg oktobar) through the lens of consumption. Moreover, the author examines the circumstances under which the privatization occurred and the connection between private investors, local authorities, and political actors. To some extent, the entire process of privatization is indicated as corrupted and controversial. Due to the lack of transparency, the unstable political and economic situation and corruption are often interconnected with the rapid urban development in postsocialist cities, especially in the early years after liberalization. Nevertheless, the analysis shows that although commercial goals and consumption guided the transformation of the shopping mall and public square, in practice, the shopping mall and its surroundings are limitedly "consumed" for commercial activities by the residents; rather, it is a place for leisure activities.

The issue continues to focus on populist urban movements emerging around East-Central Europe. O'Dwyer, analyzes urban movements in two postsocialist capitals, i.e., Prague and Warsaw, to provide answers on what kind of populism postsocialist urban movements espouse and why. The analysis shows that despite the common socialist background, Prague and Warsaw's urban movements operated in different political contexts, leading to different

\footnotetext{
${ }^{*}$ MSc Urban and Public Policy from the University of Glasgow. ksenijamart@yahoo.com
} 
mobilizing frames and tactics. In both cities, the postsocialist urban planning system showed a lack of responsiveness, and it was connected with corrupt practices, which triggered populist urban movements. In Prague, populist urban movements were more oriented to reform existing institutions using pressure-group tactics. In contrast, a more radical approach to urban movements was adopted in Warsaw, resulting in more contentious and disruptive tactics. Consequently, the results and achievements of these groups varied.

In the fourth article, Matyushkina deals with the postsocialist urban shrinking in the capital of Latvia by exploring the alternative cultural strategies and identifying the tools that could stimulate the implementation of these strategies in other areas. Riga was one of the most rapidly shrinking cities in Europe; thus, the Riga City Council decided to prioritize a pro-growth cultural strategy, i.e., cultural economy and industries, to attract investors and tourists. However, Riga's selection for the European Capital of Culture (ECoC) changed and reshaped the cultural strategy approach. With the support of the ECoC Foundation, Riga developed a set of measures with local stakeholders, which finally improved cultural accessibility for diverse social groups. The analysis suggests that this approach was successful in practice as this new innovative cultural strategy led to more inclusive, socially, and locally-driven actions.

Moreover, the analysis shows a need for a physical-cultural infrastructure to make efficient both cultural development and "software." According to the author, the success of Riga's cultural strategy also relies on local decentralization. A division of Riga into 58 neighborhoods allowed a better creation of cultural identities that have been additionally stimulated with the involvement of civic organizations. Nevertheless, the author suggests that this approach is limited to a specific case study, and its applicability to other contexts remains to be investigated.

In the fifth article, Bogdanova theoretically explores the relationship of the socialist architecture and its ideology and perception of Asenovgrad residents on the socialist town center and how it is perceived in the collective memory. The socialist architectural landscape in Bulgaria represented the state authority and a reflection of the socialist values and ideas. The analysis shows that a built socialist environment deprived the cultural specificity of Asenovgrad residents, and its memory is still connected with life "before socialism." The author suggests that socialism interrupted the cultural-historical continuity of Asenovgrad. The residents of Asenovgrad are using the Stanimashka fotografchiynitsa, a Facebook group, to recreate their historical, pre-socialist architectural identity.

The following article introduces the reader to the situation in Budapest, Hungary, which during the socialist period was, like many other socialist cities, characterized by different kinds of industrial activities. Socialist industrialization was the basis of socialism itself. Consequently, the physical and social aspects of the cities were dedicated to industry, and the shift in the ideology, resulted in a shrinking of industrial sites and the social capital of workers. Harlov-Csortán investigates what happened to industrial areas in Budapest and discusses the changes in physical space. The article shows the decay of the former industrial sites, especially in the first decade after the collapse of socialism, which combined with intensive privatization, limited resources, and other circumstances led to a diversification of sites, leaving the industrial and socialist character of locations in the past. While heritagization was one of the established purposes of these sites, the analysis shows that the appreciation of the sites is more connected to the pre-socialist period, even though some effective solutions are also introduced, such as the connection of these sites to recreational activities. 
The final article leads us to Chisinau, the capital of the Republic of Moldova, and the names of its streets, i.e., hodonyms. Romanova explores the change of socialist street names in the postsocialist period and the principles that influenced street name formation. The analysis showed the social, political, and ideological relations behind the forming and change of the street names to influence the social and urban identity. Moreover, within the analysis, the author grouped the street names in several categories, including street renaming by translating them from Russian to Romanian, replacing street names named after the wellknown soviet memorial figures, historical events, and national Moldovia figures, etc. Through the change of the street names, the reader could understand more about Moldova's path towards the national ideals and creation of the city and social identity. However, it is clear that altering street names does not change the collective memory, and the persistence of old, socialist street names is still often used by the community.

Finally, in this issue, you will get a chance to read a piece by Muguerza-Espino, who reviewed Jelisaveta Petrovic and Vera Backovic's book, published in 2019, under the title "Experiencing Postsocialist Capitalism: Urban Changes and Challenges in Serbia." The book itself focuses on the Belgrade Waterfront project, which is also marked with controversy, private interest, and interconnections between private and public actors. Nevertheless, the project itself brings ample attention from the academic community.

This issue demonstrates that the academic interest in postsocialist cities did not fade, and it seems that the authors are more focused on covering specific cases and issues in-depth. Nevertheless, examining the postsocialist cities and their trajectory remains a complex topic to investigate. The articles presented here aimed to provide material for various case studies which could contribute to understanding the changes, challenges, and in general, the postsocialist urban phenomenon. 